Available online at http://jurnal.goretanpena.com/index.php/JSSR

\title{
INFORMATION GAP ACTIVITIES AT THE NINTH GRADE OF SMP NEGERI 7 TANJUNG BALAI
}

\author{
Cecep Maulana \\ STMIK Royal, Kisaran \\ e-mail: cecep.maulana1977gmail.com
}

\begin{abstract}
The aim of this study was to described and analyze of the information Gap Activities at the ninth grade of SMP Negeri 7 Tanjung balai. This learning activity took the classroom action research. The reseacher was done in two cycles. Each Cycle consisted of three meetings. Each cycle consisted of: planning, action, observation, and reflection. Technique of collecting the data used observation, interview and test then analyzed the data both qualitatively and quantitatively. The researcher gave pre-test, test cycle 1 and test cycle 2 especially in descriptive text to measure studentse ${ }^{\text {ee }}$ speaking ability. The result of the test showed that (1) the implementation of Information Gap Activities in teaching speaking as follows. The first step, it starts giving to the student material about describing a thing, the second, the students discuss with their group to make conversation about describing something. Information Gap Activities was done in group. (2) Information Gap Activities technique can improve the students speaking ability. It can be seen from the result of pretest and posttest. Based on the result of mean score on pretest is 55.00. After the researcher taught speaking by using implementation Information Gap Activities, the studentse mean score become 69.80 in posttest 1 . Then in posttest 2, the students, mean score improves to be 80.05. Information Gap Activities technique could help the students more confident in speaking activity.
\end{abstract}

\section{Keywords: Information Gap Activities, Student's Speaking Ability, Classroom} Action Research

\begin{abstract}
Abstrak: Penelitian ini bertujuan untuk mendeskripsikan dan menganalisis Kesenjangan Informasi Kegiatan pada siswa kelas IX SMP Negeri 7 Tanjung balai. Kegiatan pembelajaran ini mengambil penelitian tindakan kelas. Peneliti dilakukan dalam dua siklus. Setiap Siklus terdiri dari tiga kali pertemuan. Setiap siklus terdiri dari: perencanaan, tindakan, observasi, dan refleksi. Teknik pengumpulan data menggunakan observasi, wawancara dan tes kemudian menganalisis data baik secara kualitatif maupun kuantitatif. Peneliti memberikan pre-test, test cycle 1 dan test cycle 2 khususnya pada teks deskriptif untuk mengukur kemampuan berbicara siswa. Hasil pengujian menunjukkan bahwa (1) penerapan Information Gap Activities dalam pengajaran berbicara sebagai berikut. Langkah pertama dimulai dengan memberikan materi kepada siswa tentang mendeskripsikan suatu hal, yang kedua, siswa berdiskusi dengan kelompoknya untuk membuat percakapan tentang mendeskripsikan sesuatu. Kegiatan Kesenjangan Informasi dilakukan secara berkelompok. (2) Teknik Information Gap Activities dapat meningkatkan kemampuan berbicara siswa. Hal ini dapat dilihat dari hasil pretest dan posttest. Berdasarkan hasil nilai rata-rata pada pretest adalah 55,00. Setelah peneliti mengajar berbicara dengan menggunakan implementasi Information Gap Activities, skor rata-rata siswa menjadi 69,80 pada posttest 1 . Kemudian pada posttest 2 , skor rata-rata siswa meningkat menjadi 80,05. Teknik Information Gap Activities dapat membantu siswa lebih percaya diri dalam kegiatan berbicara.
\end{abstract}


Available online at http://jurnal.goretanpena.com/index.php/JSSR

Kata kunci: Kegiatan Kesenjangan Informasi, Kemampuan Berbicara Siswa, Penelitian Tindakan Kelas

\section{INTRODUCTION}

Speaking is the most important skill, because it is one of the abilities to carry out conversation. One of the ways in communication is through speaking. It is very important to master speaking well. To master speaking ability, students must be trained to use English in communication orally. it has attained the status of the global language. (Parupalli Srinivas Rao, 2019). The frequency in using the language will determine the success in speaking ability. Without implementing the experience of learning the language in the real life, it is difficult for the students to master speaking ability. Besides, speaking competence can be accomplished by practicing it orally. By speaking, we can express our idea to communicate with other people.

Speaking skill is taught to students to make the capability of communicating by using English correctly and focuses on verbal interactions (Aseptiana Parmawati, Ratih Inayah, 2019). There are some elements of teaching speaking that need to be mastered namely grammar, vocabulary, pronunciation (intonation, stress, and pitch), fluency, and comprehension. Those elements are needed in teaching learning process especially in speaking skill, so that the students are capable and confident in speaking. Based on the complexities of the speaking elements like grammar, vocabulary, pronunciation, fluency and gesture, a lot of students get many problems to learn speaking.

Based on the observation of SMP Negeri 7 Tanjung balai had problems in learning English especially learning speaking. Some problems arise from the students sides: (1) the students were passive in class, during the teaching and learning process. (2) the students be noisy and talked each other when the teacher explained the materials (3) the students felt difficult to catch the teacher's explanation, there were no variations in teaching and learning process, so the students felt bored during teaching process in the class (4) the students have no motivation to learn about English language especially in speaking, they think that speaking is difficult to practice and they are not enough confident to speak.

The reasons above were also supported by the result of interview. with the students. The interview was conducted to know students' opinion about speaking ability. The students answered that speaking was difficult. The students were afraid of making mistakes in speaking English. They were not confident. They felt bored during learning process in speaking

Based on those reasons, how to solve the problems and tries to make a new method to teach English at the ninth grade of SMP Negeri 7 Tanjung balai, it could be known some information about condition of the students in the class.

An effort would be done by using Information Gap Activities. Information Gap Activities is two speakers have different bits of information, and they can only complete the whole picture by sharing that information because they have different information. In an information gap activity one person has information that the other lacks. They must use the target language to share that information (Harmer, 1991:48). For instance, one student has the directions to a party and must give them to a classmate. Information gap exists when one person in an exchange knows something to other person does not. For information gap activities to work, it is vitally important that students understand the details of the task.(for example, that they should not show each other picture). 
Available online at http://jurnal.goretanpena.com/index.php/JSSR

They give every student the opportunity to speak in the target especially for the building blocks of language we teach them to speak in the target language (Raptou, 2014). In addition, they can help to reduce such fears by maintaining a friendly atmosphere in the class and providing opportunity for students to practice alone or with another student and then increasingly with a larger group of students. It is believed that Information Gap Activities can give an element of fun to students and it can get attention from the students. ( Nurdevi Bte Abduh, 2013)

\section{METHOD}

This method used the Class room Action Research and followed cycle I and cycle II. According to Kemmis and Mc Taggart in Burns (2010:8) which is also used in this research, this method consist of four steps; planning, action, observation, and reflection. The implementation of classroom action research included four steps as follows:

\section{1) Planning}

It was developed action research after identifying problems. It included the planning about: the information Gap Activities (IGA), and how to include their activities about speaking area.

\section{2) Action}

Action is the realization which is planned before. It means that how to act what has been planned such as get the information and increase the knowledge more deeply for using Gap technique and material for them.

\section{3) Observation}

It was assisted by the collaborator about the technique of teaching in the class in the material delivery and teaching learning process, about the student's interaction, opinions, performance, and other activities written down in a field note.

\section{4) Reflection}

It would reflect on evaluate and describe the effects of the action. All the notes and field note from the researcher and the collaborator were collected and reflected. It would be used for better understanding or knowing improvement on the next planning or action.

This activity used the scorer/rater reliability. According to Kusumah, Wijaya, 2010:55) stated that scorer rater reliability refers to the situations for which reliability must be investigated, such as essay test, oral test, short answer test involving more than one word response, rating scale, and observation instrument. And used assessment speaking of oral test.

The data from the observation would take from activities during the teaching and learning process. The observation, which involved researcher, and students, it was conducted to know how the teaching and learning process in the classroom. The data would be analyzed by using qualitative and quantitative analyses. The qualitative data analyses were used to analyze the data would take during the teaching and learning process. And used the process of analyzing data that were explained by Burns (1999:156). The stages are:

1. Assembling the data

assembled the data that have collected over the period of the research: interviews, field notes and test.

2. Coding the data a code to the instrument of the data to make it more manageable.

3. Comparing the data

After coding the data, the data were compared to see whether themes were repeated across different data gathering techniques.

4. Building interpretations. described the data that have been collected, then categorizing the data such as scores of the students

5. Reporting the outcomes 
Available online at http://jurnal.goretanpena.com/index.php/JSSR

involved presenting an account of the research for others.

The quantitative data analyses were used to analyze data from the result of the teaching learning process. According to Furchan (1982:46) proposed that the procedures of research are identifying the problem, analyzing the problem, choosing the research strategy and its instrument, collecting and analyzing the data, and reporting the research result.

It was done to compare between the result of pretest (before implementing IGA) and the result of post-test (after implementing IGA). The formula of the mean of the pretest and posttest could be calculated as follows:

Notes

$$
\begin{array}{ll}
\mathrm{X} & : \text { Mean of pre test scores } \\
\mathrm{Y} & : \text { Mean of post test score } \\
\mathrm{N} & : \text { Number of subject } \\
\sum \mathrm{x} & : \text { The sum of pretest score } \\
\sum \mathrm{y} & : \text { The sum of posttest score }
\end{array}
$$$$
\text { (Sumanto,1995:210) }
$$

Based on calculation result using the formula above, it would be known whether there is improvement of the result of pretest and posttest. And compares the mean score of pre-test, post-test 1 and post-test 2 for knowing the result of students speaking ability.

\section{RESULT AND DISCUSSION}

The result of the pre-test showed that the studentse speaking was still low. It was showed from the mean score of pre-test 55. It is still lower than the minimum standard.

Table 1: The Student's Pretest Score before treatment

\begin{tabular}{|c|c|c|c|c|}
\hline & Name & Pretest & $\begin{array}{c}\text { Pass } \\
\text { Grade }\end{array}$ & $\begin{array}{c}\text { Pass/ } \\
\text { Fail }\end{array}$ \\
\hline 1 & AM & 50 & 75 & Fail \\
\hline 2 & AL & 55 & 75 & Fail \\
\hline 3 & AA & 60 & 75 & Fail \\
\hline 4 & BA & 40 & 75 & Fail \\
\hline
\end{tabular}

\begin{tabular}{|c|c|c|c|c|}
\hline 5 & CI & 50 & 75 & Fail \\
\hline 6 & UK & 60 & 75 & Fail \\
\hline 7 & YE & 80 & 75 & Pass \\
\hline 8 & YK & 55 & 75 & Fail \\
\hline 9 & AJ & 40 & 75 & Fail \\
\hline 10 & AT & 40 & 75 & Fail \\
\hline 11 & AN & 60 & 75 & Fail \\
\hline 12 & CS & 70 & 75 & Fail \\
\hline 13 & FN & 50 & 75 & Fail \\
\hline 14 & HN & 65 & 75 & Fail \\
\hline 15 & IR & 45 & 75 & Fail \\
\hline 16 & LT & 40 & 75 & Fail \\
\hline 17 & NS & 50 & 75 & Fail \\
\hline 18 & SM & 50 & 75 & Fail \\
\hline 19 & SL & 40 & 75 & Fail \\
\hline 20 & ZR & 80 & 75 & Pass \\
\cline { 1 - 2 } SUM & $\mathbf{1 . 0 8 0}$ & & \\
\cline { 2 - 3 } MEAN & $\mathbf{5 5}$ & & \\
\cline { 2 - 3 } & & &
\end{tabular}

It could be seen that the studentse speaking ability needed to be improved. And decided how to improve it through a technique that was supported by a media namely IGA. IGA is two speakers have different bits of information, and they can only complete the whole picture by sharing that information because they have different information; there is a "gap" between them. IGA could be defined as good way to combine instruction.

The purpose of posttest 1 was to know how far the studentse improvement of speaking ability using IGA. The students ${ }^{\text {ee }}$ scores were increased, but some of them that increased from pretest 55.0 in the posttest 69.8. And its improvement could be seen from table below:

Table 2: Students speaking achievement in cycle 1

\begin{tabular}{|c|c|c|c|c|}
\hline No & Name & Pretest & $\begin{array}{c}\text { Posttest } \\
1\end{array}$ & $\begin{array}{c}\text { Pass/ } \\
\text { Fail }\end{array}$ \\
\hline 1 & AT & 50 & 55 & Fail \\
\hline 2 & AS & 55 & 70 & Fail \\
\hline 3 & AK & 60 & 65 & Fail \\
\hline 4 & LR & 40 & 75 & Pass \\
\hline 5 & MT & 50 & 65 & Fail \\
\hline
\end{tabular}


Available online at http://jurnal.goretanpena.com/index.php/JSSR

\begin{tabular}{|c|c|c|c|c|}
\hline 6 & UK & 60 & 75 & Pass \\
\hline 7 & YE & 80 & 85 & Pass \\
\hline 8 & YK & 55 & 70 & Fail \\
\hline 9 & $\mathrm{AJ}$ & 40 & 60 & Fail \\
\hline 10 & AT & 40 & 65 & Fail \\
\hline 11 & AN & 60 & 75 & Pass \\
\hline 12 & CS & 70 & 78 & Pass \\
\hline 13 & FN & 50 & 68 & Fail \\
\hline 14 & $\mathrm{HN}$ & 65 & 75 & Fail \\
\hline 15 & IR & 45 & 65 & Fail \\
\hline 16 & LT & 40 & 55 & Fail \\
\hline 17 & NS & 50 & 60 & Fail \\
\hline 18 & SM & 50 & 55 & Fail \\
\hline 19 & SL & 40 & 75 & Pass \\
\hline 20 & ZR & 80 & 85 & Pass \\
\hline & SUM & 1.080 & 1376 & \\
\hline & MEAN & 55 & 69,8 & \\
\hline
\end{tabular}

\begin{tabular}{|c|c|c|c|c|}
\hline 2 & AS & 70 & 80 & Pass \\
\hline 3 & AK & 65 & 80 & Pass \\
\hline 4 & LR & 75 & 82 & Pass \\
\hline 5 & MT & 65 & 78 & Pass \\
\hline 6 & $\begin{array}{l}\mathrm{UK} \\
\end{array}$ & 75 & 85 & Pass \\
\hline 7 & YE & 85 & 85 & Pass \\
\hline 8 & YK & 70 & 78 & Pass \\
\hline 9 & AJ & 60 & 71 & Fail \\
\hline 10 & AT & 65 & 82 & Pass \\
\hline 11 & AN & 75 & 78 & Pass \\
\hline 12 & $\mathrm{CS}$ & 78 & 85 & Pass \\
\hline 13 & FN & 68 & 82 & Pass \\
\hline 14 & $\mathrm{HN}$ & 75 & 85 & Pass \\
\hline 15 & IR & 65 & 80 & Pass \\
\hline 16 & LT & 55 & 75 & Fail \\
\hline 17 & NS & 60 & 78 & Pass \\
\hline 18 & SM & 55 & 72 & Fail \\
\hline 19 & SL & 75 & 85 & Pass \\
\hline 20 & $\overline{\mathrm{ZR}}$ & 85 & 85 & Pass \\
\hline & SUM & 1376 & 1601 & \\
\hline & MEAN & 69,8 & 80.05 & \\
\hline
\end{tabular}

After diagnostic test in the cycle 1, showed that the English learning process using IGA did not run well. But there was improvement of students ${ }^{\text {ee }}$ achievement than before. It could be seen from the score of the post-test 1 .

Nevertheless, the improvement of the students ${ }^{\text {ee }}$ scores of speaking ability was not satisfying enough since there were still some students who had less attention.

From the result of the reflection above, it could be concluded that the action in the first cycle resulted was not satisfying. So, decided to take the second cycle in order to make better improvement to the students ${ }^{\text {ee }}$ speaking ability.

In here, The result showed that there were improvements toward the score. The mean score of post-test 2 was 80.05 the more detail result could be seen from the table below:

Table 3 The Comparison between the Post Test's Score in Cycle 1 and Post Test's Score in Cycle 2

\begin{tabular}{|c|c|c|c|c|}
\hline No & Name & $\begin{array}{c}\text { Posttest } \\
1\end{array}$ & $\begin{array}{c}\text { Posttest } \\
2\end{array}$ & $\begin{array}{c}\text { Pass/ } \\
\text { Fail }\end{array}$ \\
\hline 1 & AT & 55 & 75 & Fail \\
\hline
\end{tabular}

\section{CONCLUSION}

Using Information Gap Activities technique can improve the students speaking ability. It can be seen from the result of pre-test and post-test 'mean score. Based on the result of mean score on pretest is 55.00 .

In here, that was true the implementation of using Information Gap Activities at the ninth grade of SMP Negeri 7 Tanjung balai. The students 'mean score become 69.80 in post-test 1 . Then in post-test 2, the students 'mean score improves to be 80.05. Information Gap Activities technique could help the students more confident in speaking activity. During teaching and learning process using Information Gap Activities, students showed that they were more active and enthusiastic in learning Besides, they paid attention more when the researcher explained about the material using Information Gap Activities for them. 
Available online at http://jurnal.goretanpena.com/index.php/JSSR

\section{REFERENCES}

Aseptiana Parmawati, Ratih Inayah, 2019. Improving Students' Speaking Skill Through English Movie in Scope for General Comunication ELTIN Journal, Volume 7/II, October 2019.

Burns, Anne.1991. collaborative action Research for English Language Teachers. United Kingdom: Cambridge University Press.

Gay, L.R.,Mills, GeoffreyE., Peter, Airasian. Educational Research (competencies for Analysis and Application). USA:Pearson

Harmer, J. 1991. The Practice of English Language Teaching. London: Longman Group UK Limite

Kemmis, S., and McTaggart, R. (1988). The action research reader (3rd ed.) Geelong: Deakin University Press.

Kusumah, Wijaya, \& Dedi. 2010. Mengenal Penelitian Tindakan

\section{Kelas. Jakarta: PT.Indeks}

Nurdevi Bte Abduh, 2013. The Implementation of Information Gap Activities Students' Speaking and Reading Skills. Exposure English Education Department Vol. 2 No. 1 Mei 2013.

Parupalli Srinivas Rao, 2019. The Importance of Speaking Skills in English Classrooms. Alford Council of International English \& Literature Journal(ACIELJ)

Raptou, V. (2014). Using information gap activities in the second language classroom. Canadian Association of Second Language Teachers (CASLT), https://www.caslt.org

Sumanto. 1995. Metodologi Penelitian Sosial dan Pendidikan. Yogyakarta:Andi Offset 